\title{
Dietary energy level for optimum productivity and carcass characteristics of indigenous Venda chickens raised in closed confinement
}

\author{
O.J. Alabi", J.W. Ng'ambi \& D. Norris \\ Department of Agricultural Economics and Animal Production, University of Limpopo, \\ Private Bag X1106, Sovenga 0727, South Africa
}

(Received 12 October 2012; Accepted 30 January 2013; First published online 5 August 2013)

Copyright resides with the authors in terms of the Creative Commons Attribution 2.5 South African Licence.

See: http://creativecommons.org/licenses/by/2.5/za/

Condition of use: The user may copy, distribute, transmit and adapt the work, but must recognise the authors and the South African Journal of Animal Science

\begin{abstract}
A study was conducted to determine dietary energy levels for optimum productivity and carcass characteristics of indigenous Venda chickens raised in closed confinement. Four dietary treatments were considered in the first phase (1 to 7 weeks) on two hundred day-old unsexed indigenous Venda chicks indicated as $\mathrm{EVS}_{1}, \mathrm{EVS}_{2}, \mathrm{EVS}_{3}$ and $\mathrm{EVS}_{4}(11,12,13$ and $14 \mathrm{MJ} \mathrm{ME} / \mathrm{kg} \mathrm{DM}$, respectively) and each treatment was replicated five times. In the second phase (8 - 13 weeks), 160 indigenous Venda female chickens, aged eight weeks, were randomly allocated to four dietary treatments and each treatment was replicated five times in a completely randomized design. The diets used in both trials were isonitrogenous but with different energy levels. A quadratic equation was used to determine dietary energy levels for optimum feed intake, growth rate, FCR and ME intake at both the starter and grower phases and the carcass characteristics of the birds at 91 days. Dietary energy levels of 12.91, 12.42, 12.34 and 12.62 MJ ME/kg DM feed supported optimum feed intake, growth rate, FCR and ME intake, respectively, for the starter phase. At the grower phase, dietary energy levels of 12.56, 12.66, 12.62 and $12.71 \mathrm{MJ} \mathrm{ME} / \mathrm{kg} \mathrm{DM}$ feed supported optimum feed intake, growth rate, FCR and ME intake, respectively. Carcass, drumstick, thigh and wing had optimum weights at dietary energy levels of 13.81, 13.23, 13.43 and $13.18 \mathrm{MJ}$ ME/ kg DM, respectively. Thus, dietary energy level for optimization depended on the particular production parameter in question.
\end{abstract}

Keywords: Metabolisable energy, optimization, quadratic equation, digestibility

"Corresponding author: alabioj@gmail.com

\section{Introduction}

There is inconsistent information about the optimal dietary energy requirements for indigenous chickens. Tadelle \& Ogle (2000) reported that energy requirement of indigenous chickens as determined from the chemical analysis of the crop contents is 11.99 MJ ME $/ \mathrm{kg}$. The NRC (1994), however, recommended that the required energy in growing indigenous chicken diets should be $12.14 \mathrm{MJ} \mathrm{ME} / \mathrm{kg}$. Furthermore, Payne (1990) recommended 11.46 MJ ME/kg DM feed for one to six weeks of growth and $10.86 \mathrm{MJ} \mathrm{ME} / \mathrm{kg}$ feed during the 6 to 12 weeks of the growing period. Mbajiorgu (2010) reported that a diet containing a crude protein content level of $178 \mathrm{~g}$ per $\mathrm{kg}$ DM and energy level of 14 MJ ME per kg DM allowed for optimal utilization of absorbed protein and energy for growth of Venda chickens between one and six weeks old. Thus, because information on dietary energy requirements for indigenous chickens is limiting and not conclusive, the objective of this study was to determine dietary energy levels for optimum productivity and carcass characteristics of indigenous Venda chickens. 


\section{Materials and Methods}

This study was conducted at the Animal Unit of the University of Limpopo, South Africa. The ambient temperatures around the study area ranged between 20 and $36{ }^{\circ} \mathrm{C}$ during summer and between 10 and $25^{\circ} \mathrm{C}$ in winter. University of Limpopo lies at latitude $27.55 \mathrm{~S}$ and longitude $24.77 \mathrm{E}$. It receives a mean annual rainfall of less than $400 \mathrm{~mm}$ (Kutu \& Asiwe, 2010).

The first experiment was done to determine the effect of varying energy levels on productivity of unsexed indigenous Venda chicks between the ages of 1 and 7 weeks old. Two hundred unsexed day-old indigenous Venda chicks were randomly allocated to four dietary treatments of varying energy levels indicated as $\mathrm{EVS}_{1}(11 \mathrm{MJ} \mathrm{ME} / \mathrm{kg} \mathrm{DM}), \mathrm{EVS}_{2}$ (12 MJ ME/kg DM), EVS ${ }_{3}(13 \mathrm{MJ} \mathrm{ME} / \mathrm{kg} \mathrm{DM})$ and EVS 4 (14 MJ ME/kg DM). Each treatment was replicated five times in a completely randomized design. Each replicate had 10 chicks, and 20 floor pens measuring $2.5 \mathrm{~m}^{2}$ in area were used. The formulated experimental diets were isonitrogenous (180 g CP/kg DM, based mainly on maize and soya beans), but with different energy levels. The birds were offered feed and fresh water ad libitum. Twenty three hours of light was available per day. The experiment was terminated when the birds were 49 days old.

The second experiment was done to determine the effect of varying energy levels for optimum productivity and carcass characteristics of indigenous Venda female chickens aged 8 to 13 weeks. The design, treatments and layout for the second experiment were similar to those in the first experiment, except that 160 seven-week-old indigenous Venda female chickens were randomly allocated to four dietary treatments. Each treatment was replicated four times with 10 birds per replicate. Prior to this experiment, the chickens were fed a $180 \mathrm{~g} \mathrm{CP} / \mathrm{kg} \mathrm{DM}$ and $12.14 \mathrm{MJ} \mathrm{ME} / \mathrm{kg} \mathrm{DM}$ diet to meet their nutritional requirements according to NRC (1994). These two experiments were carried out simultaneously between January and March 2012.

The initial live weights of the birds were taken at the beginning of each experiment and at weekly intervals thereafter. Feed intake, growth rate, feed conversion ratio and digestibility were determined according to the procedures of McDonald et al. (2011).

At 91 days of age all remaining birds in each pen from Experiment 2 were slaughtered by cervical dislocation as recommended by the University of Limpopo Committee on Animal Ethics. Carcass weight, breast meat, drumstick, thigh and wing weights were determined.

Dry matter contents of the diets, refusals and faecal samples were determined as described by AOAC (2008). The gross energy of the diets and faecal samples were determined (AOAC, 2008) using a bomb calorimeter (Animal Production Laboratory, University of Limpopo). The apparent metabolisable energy contents of the diets were determined according to AOAC (2008) official methods.

Data in both trials were analysed by one-way analysis of variance (SAS, 2010). Treatment means were separated using the least significant difference (95\% confidence level). The responses in feed intake, growth rate, feed conversion ratio, ME, carcass, breast meat yield, drumstick, thigh and wing weights to energy levels were modelled using the following quadratic equation (SAS, 2010):

$$
\mathrm{Y}=\mathrm{a}+\mathrm{b}_{1} \mathrm{x}+\mathrm{b}_{2} \mathrm{x}^{2}
$$

where Y represents feed intake, growth rate, feed conversion ratio, ME, carcass, breast meat, drumstick, thigh and wing; $a$ is the intercept; $b$ is the coefficients of quadratic equation; $x$ is the dietary energy level and $-b_{1} / 2 b_{2}=x$ value for optimum response. The quadratic model was fitted to the experimental data by means of the NLIN procedure of SAS (SAS, 2010). The quadratic model was used because it gave the best fit.

\section{Results and discussion}

Dry matter intakes increased $(P<0.05)$ as dietary energy levels increased until optimums of 37.3 and $59.85 \mathrm{~g} /$ bird/day for starter and grower phases, respectively, were reached. Thereafter, feed intake on dry matter basis decreased. This is, possibly, because the chickens had met their energy requirements and hence there was no need to increase their intakes further (NRC, 1994; Fan et al., 2008; Mbajiorgu et al., 2011). The present optimal dietary energy values for intake are similar to those of Mbajiorgu (2010). However, the values obtained from the Venda chickens are lower than those for broiler chickens as proposed by NRC (1994). Differences in dietary energy levels for optimal feed intake between Venda and broiler chickens may be related to differences in energy requirements (NRC, 1994; Mbajiorgu 2010; Mbajiorgu et al., 2011). Tang 
et al. (2007) reported that differences in responses to dietary energy levels might be attributed to breed differences. Such differences may be due to gene encoding key regulatory factors such as hormones, enzymes and metabolic pathways (Richards \& Proszkowiec-Weglarz, 2007). Emmans \& Fisher (1986) and Emmans (1989) indicated that chickens grow based on their genetic potential; thus, they attempt to eat as much of a given feed as would be required to satisfy their growth needs.

Growth rate increased $(P<0.05)$ as the dietary energy levels increased until a level of $12.42 \mathrm{MJ} \mathrm{ME} / \mathrm{kg}$ DM feed for optimal growth rates of $9.23 \mathrm{~g} / \mathrm{bird} /$ day was reached at starter phase. Similarly, at the grower phase growth rate increased $(P<0.05)$ as the dietary energy levels increased until a level of $12.62 \mathrm{MJ} \mathrm{ME} / \mathrm{kg}$ DM feed for optimal growth rate of $22.67 \mathrm{~g} / \mathrm{bird} /$ day was reached (Tables 1 and 2). Thus, optimal dietary energy levels for growth rates at starter and grower phases were different. The reason may be that the chickens met their energy requirements at those levels and hence any additional energy content did not contribute much to the growth of the chickens (Mbajiorgu et al., 2011). Ng'ambi et al. (2009) and Mbajiorgu et al. (2011) reported that growth rates at starter and grower phases were optimal at different levels when chickens were fed varying lysine to crude protein and lysine to energy levels, respectively.

Table 1 Effect of varying dietary energy level on mean feed intake (g/bird/day), growth rate (g/bird/day), feed conversion ratio (FCR), metabolisable energy (ME) intake (MJ/kg DM) (ME) and mortality rate (\%) of indigenous Venda chickens

\begin{tabular}{|c|c|c|c|c|c|}
\hline \multirow{2}{*}{ Characteristic } & \multicolumn{4}{|c|}{ Diet } & \multirow{2}{*}{$\mathrm{SE}$} \\
\hline & $\mathrm{EVS}_{1}$ & $\mathrm{EVS}_{2}$ & $\mathrm{EVS}_{3}$ & $\mathrm{EVS}_{4}$ & \\
\hline \multicolumn{6}{|c|}{ Unsexed Venda chicks (1 - 7 weeks) } \\
\hline Feed intake & $30.3^{c}$ & $33.9^{\mathrm{b}}$ & $37.3^{\mathrm{a}}$ & $34.1^{\mathrm{b}}$ & 0.77 \\
\hline Growth rate & $8.7^{\mathrm{c}}$ & $9.1^{\mathrm{b}}$ & $9.4^{\mathrm{a}}$ & $8.4^{\mathrm{d}}$ & 0.11 \\
\hline FCR & $3.5^{\mathrm{d}}$ & $3.7^{\mathrm{c}}$ & $4.0^{\mathrm{b}}$ & $4.1^{\mathrm{a}}$ & 0.08 \\
\hline ME & $8.8^{\mathrm{c}}$ & $10.8^{\mathrm{a}}$ & $10.7^{\mathrm{a}}$ & $9.6^{\mathrm{b}}$ & 0.25 \\
\hline Mortality & 1.4 & 1.4 & 1.4 & 1.4 & 0.08 \\
\hline \multicolumn{6}{|c|}{ Venda female chickens (8 - 13 weeks) } \\
\hline Feed intake & $57.1^{\mathrm{d}}$ & $64.3^{c}$ & $69.5^{\mathrm{a}}$ & $65.6^{\mathrm{b}}$ & 1.35 \\
\hline Growth rate & $19.6^{c}$ & $22.2^{\mathrm{a}}$ & $22.5^{\mathrm{a}}$ & $20.7^{b}$ & 0.36 \\
\hline FCR & $3.6^{\mathrm{a}}$ & $2.5^{\mathrm{d}}$ & $2.9^{\mathrm{c}}$ & $3.2^{\mathrm{b}}$ & 0.12 \\
\hline ME & $9.8^{\mathrm{d}}$ & $11.7^{\mathrm{b}}$ & $12.6^{\mathrm{a}}$ & $9.2^{\mathrm{c}}$ & 0.44 \\
\hline Mortality & 0.0 & 0.0 & 0.1 & 0.0 & 0.00 \\
\hline
\end{tabular}

${ }^{\mathrm{a}, \mathrm{b}, \mathrm{c}, \mathrm{d}}$ Means in the same row not sharing a common superscript are different $(P<0.05)$.

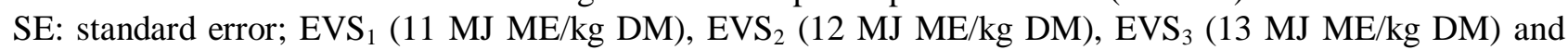
$\mathrm{EVS}_{4}(14 \mathrm{MJ} \mathrm{ME} / \mathrm{kg} \mathrm{DM})$.

The ME values increased $(P<0.05)$ as the dietary energy increased reaching optimal ME values of 12.62 and $12.72 \mathrm{MJ} / \mathrm{kg} \mathrm{DM}$ for starter and grower phases, respectively (Tables 1 and 2). This could be attributed to higher energy demand as the birds grew older (NRC, 1994). This is similar to what was obtained in broiler chickens by Latshaw (2008).

Chickens fed on dietary ME levels of 10 and $11 \mathrm{MJ} / \mathrm{kg}$ DM had the better $(P<0.05)$ feed conversion ratios at starter and grower phases, respectively. However, dietary energy levels of 12.3 and $12.62 \mathrm{MJ} \mathrm{ME} / \mathrm{kg}$ DM optimized feed conversion ratios at starter (4.31) and grower (2.63) phases, respectively (Table 3). These values are higher than the $11.99 \mathrm{MJ} \mathrm{ME} / \mathrm{kg}$ DM feed recommended by Tadelle \& Ogle (2000) and the 12.14 MJ ME/kg DM feed recommended by NRC (1994) for indigenous chickens. The values observed in the present study were, however, lower than $12.54 \mathrm{MJ} \mathrm{ME} / \mathrm{kg} \mathrm{DM}$ for 5 - 8 weeks old chicks and higher than the 10.87 MJ ME/kg DM feed for 8 - 14 weeks old chickens reported by Chemjor (1998). Dibner \& Richards 
(2004) and Jafarnajad \& Sadegh (2011) reported that as the chickens grew older higher levels of dietary energy improved the feed conversion ratio.

Table 2 Dietary energy for optimum productivity and carcass characteristics of indigenous Venda chickens during the starter and grower stages

\begin{tabular}{llrrr}
\hline Trait & \multicolumn{1}{c}{ Formula } & $\mathrm{r}^{2}$ values & $\mathrm{X}$ & $\mathrm{Y}$ - value \\
\hline Starter $(1-7$ weeks) & & & & \\
$\quad$ Feed intake (g/bird/day) & $\mathrm{Y}=-248.43+44.01 \mathrm{X}-1.70 \mathrm{X}^{2}$ & 0.89 & 12.91 & 36.36 \\
$\quad$ Growth rate (g/ bird/day) & $\mathrm{Y}=-44.70+8.70 \mathrm{X}-0.35 \mathrm{X}^{2}$ & 0.85 & 12.42 & 9.32 \\
$\quad$ Feed conversion ratio & $\mathrm{Y}=-1911.75+381.82 \mathrm{X}-15.40 \mathrm{X}^{2}$ & 0.90 & 12.34 & 4.31 \\
$\quad$ ME intake (MJ) & $\mathrm{Y}=-111.60+19.39 \mathrm{X}-0.77 \mathrm{X}^{2}$ & 0.95 & 12.62 & 10.96 \\
Grower (7 - 13 weeks) & & & & \\
$\quad$ Feed intake (g bird/day) & $\mathrm{Y}=599.38-85.87 \mathrm{X}+3.42 \mathrm{X}^{2}$ & 0.60 & 12.56 & 59.85 \\
Growth rate (g/ bird/day) & $\mathrm{Y}=-155.08+28.07 \mathrm{X}-1.11 \mathrm{X}^{2}$ & 0.98 & 12.66 & 22.67 \\
Feed conversion ratio & $\mathrm{Y}=57.06-8.63 \mathrm{X}+0.34 \mathrm{X}^{2}$ & 0.87 & 12.62 & 2.63 \\
ME intake (MJ) & $\mathrm{Y}=-197.82+33.44 \mathrm{X}-1.32 \mathrm{X}^{2}$ & 0.98 & 12.71 & 14.55 \\
Carcass weight & $\mathrm{Y}=-14661.22+2439.65 \mathrm{X}-94.74 \mathrm{X}^{2}$ & 0.95 & 12.80 & 1044.38 \\
Breast meat & $\mathrm{Y}=-1971.79+327.34 \mathrm{X}-12.37 \mathrm{X}^{2}$ & 0.91 & 13.23 & 192.86 \\
Drumstick & $\mathrm{Y}=-1289.65+210.84 \mathrm{X}-7.85 \mathrm{X}^{2}$ & 0.95 & 13.43 & 126.02 \\
Thigh & $\mathrm{Y}=-1406.17+233.04 \mathrm{X}-8.84 \mathrm{X}^{2}$ & 0.95 & 13.18 & 129.45 \\
Wing & $\mathrm{Y}=-1417.29+234.69 \mathrm{X}-9.02 \mathrm{X}^{2}$ & 0.91 & 13.00 & 108.43 \\
& & & &
\end{tabular}

$\mathrm{X}=$ optimal dietary energy level; $\mathrm{Y}=$ optimal production.

Table 3 Effect of varying dietary energy levels on the carcass characteristics (g) of indigenous Venda chickens aged 91 days

\begin{tabular}{|c|c|c|c|c|c|}
\hline \multirow{2}{*}{ Characteristic } & \multicolumn{4}{|c|}{ Diet } & \multirow{2}{*}{ SE } \\
\hline & $\mathrm{EVF}_{1}$ & $\mathrm{EVF}_{2}$ & $\mathrm{EVF}_{3}$ & $\mathrm{EVF}_{4}$ & \\
\hline Carcass weight & $724.0^{d}$ & $933.5^{b}$ & $1081.2^{\mathrm{a}}$ & $911.7^{c}$ & 38.29 \\
\hline Breast meat & $134.8^{\mathrm{d}}$ & $164.5^{c}$ & $202.0^{\mathrm{a}}$ & $182.2^{\mathrm{b}}$ & 7.47 \\
\hline Drumstick & $81.3^{\mathrm{d}}$ & $105.1^{c}$ & $129.5^{\mathrm{a}}$ & $121.8^{b}$ & 5.59 \\
\hline Thigh & $88.7^{\mathrm{d}}$ & $113.5^{c}$ & $132.8^{\mathrm{a}}$ & $122.3^{b}$ & 4.98 \\
\hline Wing & $73.9^{c}$ & $94.3^{b}$ & $113.5^{\mathrm{a}}$ & $97.7^{\mathrm{b}}$ & 4.29 \\
\hline
\end{tabular}

a, b, c, d Means in the same row not sharing a common superscript are different $(P<0.05)$.

SE: standard error; $\mathrm{EVF}_{1}(11 \mathrm{MJ} \mathrm{ME} / \mathrm{kg} \mathrm{DM}), \mathrm{EVF}_{2}(12 \mathrm{MJ} \mathrm{ME} / \mathrm{kg} \mathrm{DM}), \mathrm{EVF}_{3}(13 \mathrm{MJ} \mathrm{ME} / \mathrm{kg} \mathrm{DM})$ and $\mathrm{EVF}_{4}(14 \mathrm{MJ} \mathrm{ME} / \mathrm{kg} \mathrm{DM})$.

Indigenous Venda chicken carcass characteristics were improved $(P<0.05)$ with increasing dietary energy levels. Leeson et al. (1996) and Nahashon et al. (2006) found that carcass weight was significantly improved by increasing dietary energy levels. This might be attributed to the storage of energy in adipose tissues once the requirements for basal metabolic rate and thermogenesis had been met (Leeson et al., 1996). Carcass, breast meat, drumstick, thigh and wing weights were optimal at different dietary energy levels of 12.80, 13.23, 13.43, 13.18 and 13.00 MJ ME/kg DM, respectively (Tables 2 and 3). This indicates that dietary energy requirements of indigenous Venda chickens for optimal carcass characteristics will depend on 
the production variable in question. No report was found on the effect of dietary energy level on optimal carcass characteristics of Venda chickens.

\section{Conclusion}

Dietary energy levels of 12.42 and $12.66 \mathrm{MJ} \mathrm{ME} / \mathrm{kg} \mathrm{DM}$, in a diet of $180 \mathrm{~g} \mathrm{CP} / \mathrm{kg} \mathrm{DM}$, supported optimum growth rates at starter and grower phases of Venda chickens, respectively. Furthermore, carcass, breast meat, drumstick, thigh and wing weights were optimal at different dietary energy levels of 12.80, 13.23, 13.43, 13.18 and 13.00 MJ ME/kg DM, respectively. Thus, different production parameters were optimized at different dietary energy levels. Therefore, dietary energy level for optimization depended on the particular parameter of interest. This has implications on diet-formulation for indigenous chickens.

\section{Acknowledgements}

The authors would like to acknowledge the National Research Foundation (NRF) and VLIR for their financial support.

\section{References}

AOAC, 2008. Association of Analytical Chemists, Official Methods of Analysis, $17^{\text {th }}$ ed., A.O.A.C., Washington, D.C., USA.

Chemjor, W., 1998. Energy and protein requirements of indigenous chickens of Kenya. MSc thesis, Egerton University, Kenya, pp. 83.

Dibner, J.J. \& Richards, J.D., 2004. The digestive system: challenges and opportunities. J. Appl. Poult. Res. 13, 86-93.

Emmans, G.C., 1989. The growth of turkeys. In: Recent Advances in Turkey Science. Eds: Nixey, C. \& Grey, T.C., London, Butterworths. pp. 135-166.

Emmans, G.C. \& Fisher, C., 1986. Problems in nutritional theory. In: Nutrient Requirements of Poultry and Nutritional Research. Eds: Fisher, C. \& Boorman, K.N., Butterworths Emmans \& Fisher, London. pp. 9-39.

Fan, H.P., Xie, M., Wang, M.M., Hou, S.S. \& Huang, W., 2008. Effects of dietary energy on growth performance and carcass quality of white growing Pekin ducks from two to six weeks of age. Poult. Sci. 87, 1162-1164.

Jafarnajad, S. \& Sadegh, M., 2011. The effects of different levels of dietary protein, energy and using fat on the performance of broiler chicks at the end of the third weeks. Asian J. Poult. Sci. 5, 35-40.

Kutu, F.R. \& Asiwe, J.A.N., 2010. Assessment of maize and dry bean productivity under different intercrop systems and fertilization regimes. Afr. J. Agric. Res. 5 (13), 1627-1631.

Latshaw, J.D., 2008. Daily energy intake of broiler chickens is altered by proximate nutrient content and form of the diet. Poult. Sci. 87, 89-95.

Leeson, S., Caston, L. \& Summers, J.D., 1996. Broiler response to diet energy. Poult. Sci. J. 75, 529-535.

Mbajiorgu, C.A., 2010. Effect of dietary energy to protein ratio levels on growth and productivity of indigenous Venda chickens raised in close confinement from one day up to 13 weeks of age. $\mathrm{PhD}$ thesis, Animal Production Department, University of Limpopo, South Africa.

Mbajiorgu, C.A., Ngambi, J.W., Norris, D. \& Alabi, O.J., 2011. Effect of dietary lysine to energy to ratio on performance of unsexed indigenous Venda chickens. Asian J. Anim. Vet. Adv. 6 (5), 517-524.

McDonald, P., Edwards, R.A., Greenhalgh, J.F.D., Morgan, C.A., Sinclair, L.A. \& Wilkinson, R.G., 2011. Animal Nutrition. Seventh ed., Prentice Hall. London.

Nahashon, S., Adefope, N., Amenyenu, A. \& Wright, D., 2006. Effect of varying metabolisable energy and crude protein concentrations in diets of pearl gray guinea fowl pullets 1. Growth performance. Poult. Sci. J. 85, 1847-1854.

Ng'ambi, J.W., Maoba, S.M., Norris, D., Malatje, M.S. \& Mbajiorgu, C.A., 2009. Effect of dietary lysine to crude protein ratio on performance of male Ross 308 broiler chickens. Trop. Anim. Health Prod. 41, 11-16.

NRC, 1994. Nutrient Requirements of Poultry. $9^{\text {th }}$ Revised edition. National Academy Press: Washington, D.C., USA. 
Payne, W.J.A., 1990. An Introduction to Animal Husbandry in the Tropics, $4^{\text {th }}$ ed. Longman Scientific and Technical, Essex and New York. pp. 684-744.

Richards, M.P. \& Proszkowiec-Weglarz, M., 2007. Mechanisms regulating feed intake, energy expenditure and body weight in poultry. Poult. Sci. 86, 1478-1490.

SAS, 2010. Statistical Analysis System. SAS User Guide: Release 9.2. SAS Institute Inc, Cary N.C., USA.

Tadelle, D. \& Ogle, B., 2000. Nutritional status of village poultry in the central highlands of Ethiopia as assessed by analyses of crop contents. Ethiopian J. Agric. Sci.17, 47-57.

Tang, M.Y, Ma, Q.G., Chen, Z.D. \& Ji, C., 2007. Effects of dietary metabolizable energy and lysine on carcass characteristics and meat quality in arbor acres broilers. Asian-Aust. J. Anim. Sci. 20, 1865-1873. 